9-3-2008

\title{
Statins Induce Apoptosis in Ovarian Cancer Cells Through Activation of JNK and Enhancement of Bim Expression
}

Hongli Liu

Medical College of Xi'an Jiaotong University,

Shu-Ling Liang

Harvard Medical School, sliang@bidmc.harvard.edu

Sheetal Kumar

Cleveland State University

Crystal M. Weyman

Cleveland State University, c.weyman@csuohio.edu

Wendy Liu

Case Western Reserve University, Wendy.Liu@UHHospitals.org

Follow this and additional works at: https://engagedscholarship.csuohio.edu/scibges_facpub See next page for additional authors

Part of the Cancer Biology Commons

How does access to this work benefit you? Let us know!

Publisher's Statement

(C) Springer-Verlag 2008

\section{Recommended Citation}

Liu, H., Liang, S., Kumar, S., Weyman, C. M., Liu, W., , \& Zhou, A. (2009). Statins induce apoptosis in ovarian cancer cells through activation of JNK and enhancement of Bim expression. Cancer Chemotherapy and Pharmacology, 63(6), 997 - 1005. doi:10.1007/s00280-008-0830-7

This Article is brought to you for free and open access by the Biological, Geological, and Environmental Sciences Department at EngagedScholarship@CSU. It has been accepted for inclusion in Biological, Geological, and Environmental Faculty Publications by an authorized administrator of EngagedScholarship@CSU. For more information, please contact library.es@csuohio.edu. 


\section{Authors}

Hongli Liu, Shu-Ling Liang, Sheetal Kumar, Crystal M. Weyman, Wendy Liu, and Aimin Zhou 


\title{
Statins induce apoptosis in ovarian cancer cells through activation of JNK and enhancement of Bim expression
}

\author{
Hongli Liu • Shu-Ling Liang • Sheetal Kumar • \\ Crystal M. Weyman · Wendy Liu • Aimin Zhou
}

\begin{abstract}
Purpose Ovarian cancer is the leading cause of death among all gynecological malignancies in Western countries. Although therapy for ovarian cancer has been greatly improved in the past 20 years, the overall survival for patients with advanced ovarian cancer has not changed significantly. The poor survival rates in patients with advanced ovarian cancer are due both to late diagnosis and to lack of effective drugs for the majority of patients who have a relapse and develop resistance to current chemotherapy agents used for ovarian cancer. Thus, developing and discovering effective novel drugs with different molecular structures from conventional chemotherapy agents have become an urgent clinical need.
\end{abstract}

\section{H. Liu}

The First Affiliated Hospital,

Medical College of Xi' an Jiaotong University,

710061 Xi'an, China

\section{S.-L. Liang}

Department of Pathology, Beth Israel Deaconess Medical Center,

Harvard Medical School, Boston, MA 02215, USA

C. M. Weyman

Department of BGES, Cleveland State University,

Cleveland, OH 44115, USA

W. Liu

Department of Pathology,

Case Western Reserve University,

Cleveland, OH 44106, USA

H. Liu · S. Kumar · A. Zhou ( $₫)$

Clinical Chemistry Program, Department of Chemistry,

SI 424, Cleveland State University, Cleveland,

OH 44115, USA

e-mail: a.zhou@csuohio.edu
Methods Ovarian cancer cells were treated with lovastatin and atorvastatin. Apoptosis in these cells and tumor formation in soft agar were determined. The molecular mechanism by which statins suppress ovarian cancer cell growth was evaluated.

Results Both lovastatin and atorvastatin effectively induced apoptosis in ovarian cancer cells and suppressed anchorage-independent growth of these cells in soft agar. Further investigation of the molecular mechanism has revealed that the expression of $\mathrm{Cdc} 42$ and Rac1, small GTPase family members, was highly induced in the cells by these statins along with the activation of Jun $\mathrm{N}$-terminal kinases (JNK). In addition, Bim, a proapoptotic protein, was significantly induced by these statins.

Conclusions Our findings provide new insight into the molecular mechanism by which statins induce apoptosis in ovarian cancer cells and may lead to novel therapies for advanced ovarian cancer.

Keywords Statin $\cdot$ Apoptosis $\cdot$ Small GTPase · Ovarian cancer

\section{Introduction}

Ovarian cancer is the leading cause of death among gynecological malignancies in the Western countries and affects nearly 1 in 70 women aged 50-70 years [1]. According to the American Cancer Society, approximately 21,650 women will be diagnosed with ovarian cancer, and over 15,520 will die from this disease in 2008 , in the United States [2]. Ovarian cancer has the highest mortality of all cancers associated with the female reproductive system, which reflects, in part, a lack of early symptoms and the associated difficulty of early detection. Thus, ovarian 
cancer is often diagnosed at an advanced stage. Most patients with ovarian cancer at an advanced stage are treated with cytoreductive surgery, followed by combination chemotherapy. Although an initial complete clinical response to chemotherapy is seen in $70 \%$ of patients, the majority of these patients will experience recurrence of the disease within 2 years and the 5-year survival rates are approximately 20-25\% [3]. The first-line chemotherapy drugs approved by the Food and Drug Administration (FDA) for advanced ovarian cancer include platinum-containing drugs, such as cisplatin and carboplatin. These drugs as well as paclitaxel, a taxane compound, are classified as anti-microtubular agents. Other agents, including hexamethylmelamine, topotecan, and pegylated liposomal doxorubicin, are used as second-line chemotherapy [4, 5]. However, patients with recurrent ovarian cancer usually develop resistance to these drugs. Therefore, development and discovery of new drugs capable of prolonging survival either by increasing long-term remission rates and/or duration of effective first-line treatment or to augment the efficacy of second-line treatment have become an urgent clinical need.

The statin drug family has been used successfully in the treatment of hypercholesterolemia for more than a decade. To date, they are still the most powerful drugs for lowering cholesterol levels in blood [6-8]. In recent years, statins have been considered as potent candidates for treating malignant diseases including acute myelogenous leukemia, lymphoma, squamous cell carcinomas, colorectal cancer, breast cancer and melanoma. The anticancer function of statins is based on preclinical evidence of their antiproliferative, pro-apoptotic and anti-invasive properties. Statins can induce apoptosis and inhibit proliferation in a variety of cancer cell types [9-13]. In vivo studies have revealed that statins can inhibit tumor cell growth, invasion and metastasis [14-16]. In addition, statins sensitize cancer cells to chemotherapy drugs [17-19]. Lovastatin treatment enhances the antitumor activity of doxorubicin, a common chemotherapeutic agent for a wide range of cancer [20]. A combination of atorvastatin and celecoxib synergistically induces cell cycle arrest and apoptosis in colon cancer cells [21].

Statins are inhibitors of HMG-CoA reductase and thus affect the prenylation of Rho family of small GTPases including Rac and Cdc42. Although the expectation is that statin would inhibit signaling by these GTPases, recent reports indicate that lovastatin can increase expression of Rho and cause an increase in the active form of Rho:GTP [22]. These GTPases exert similar biological activities in cells. However, each of them can also mediate distinct cellular functions through interaction with down-stream effector proteins in different cell types [23, 24]. Well-documented evidence has also shown that there are extensive cross talk and cooperation between GTPases and other signal transduction pathways. Rac1 and Cdc42 can synergize with Raf to activate ERK [25-27]. Furthermore, Rac1 cooperates with PI-3 kinase in controlling cell migration and polarity [28]. Interestingly, these small GTPases are found to mediate apoptosis in a wide-range of cell types. Overexpression of active Cdc42 in Jurkat $\mathrm{T}$ lymphocytes induces increased ceramide levels, resulting in cell death [29, 30]. Both Rac1 and Cdc42 mediate apoptosis induced by diverse stimuli [31]. It seems that the contribution of Rac1 and Cdc42 to apoptosis is to regulate mainly activation of the JNK pathway [32-34].

The effect of statins on ovarian cancer cell lines is limited to one study showing lovastatin-induced growth inhibition [35]. Here we report that statins induce apoptosis in ovarian cancer cells and inhibit tumor formation in soft agar. Further, we report the novel findings that statins can also induce the expression of Rac 1 and Cdc42, and subsequently JNK activity. Our results suggest that statins alone or in combination with other conventional drugs may provide novel therapies for advanced ovarian cancer.

\section{Materials and methods}

Reagents and antibodies

Lovastatin (Mevinolin), atorvastatin,farnesylpryophosphate (FPP), geranylgeranylpyrophosphate (GGPP), and SP600125, were from Sigma. Antibodies to RhoA, Rac1, Cdc42, phospho-c-Jun and $\beta$-actin were from Santa Cruz Biotechnology, Inc. Antibodies were from different companies: Bcl-2 from R\&D system (Minneapolis, MN), Bim and Bax from BD Bioscience (San Jose, CA). The antibody to $\beta$-Actin was purchased from Chemicon (Temecula, CA).

Cell culture and assay for cell viability

Hey 1B cells (Dr. Yan Xu, University of Indiana) and Ovcar-3 (ATCC) cells were grown in RPMI-1640 (Cleveland Clinic Foundation Core Facility) supplemented with $10 \%$ cosmic calf serum (Hyclone) and antibiotics in a humidified atmosphere of $5 \% \mathrm{CO}_{2}$ at $37^{\circ} \mathrm{C}$. The viability of Hey $1 \mathrm{~B}$ cells was determined using the colorimetric CellTiter 96 aqueous Cell Proliferation Assay (MTT) according to the instructions provided by the manufacturer (Promega, Madison, WI). Briefly, cells $\left(1 \times 10^{4}\right.$ cells per well $)$ were seeded in 96-well plates. One day after seeding, the cells were treated with or without $10 \mu \mathrm{M}$ lovastatin in the presence or absence of $5 \mu \mathrm{M}$ GGPP or $5 \mu \mathrm{M}$ FPP for $48 \mathrm{~h}$. At the end of incubation, $50 \mu$ CellTiter 96 Aqueous reagent ( $40 \% \mathrm{v} / \mathrm{v}$ dilution in $1 \times \mathrm{PBS}$ ) was added to each well. Plates were incubated at $37^{\circ} \mathrm{C}$ for $2 \mathrm{~h}$, and absorbance was 
measured at $490 \mathrm{~nm}$ with a 96 -well plate reader (model Spectra Max 340; Molecular Devices).

\section{Annexin V assay}

Annexin $\mathrm{V}$ assay was performed using an Annexin V-FITC/propidium iodine apoptosis detection kit (BD Biosciences, San Jose, CA). Briefly, cells treated with or without $10 \mu \mathrm{M}$ of lovastatin for $48 \mathrm{~h}$ were scraped and centrifuged at $1,000 \times g$ for $10 \mathrm{~min}$ at $4^{\circ} \mathrm{C}$, and washed with ice cold PBS, and then resuspended in $1 \times$ binding buffer provided by the manufacturer at a concentration of $1 \times 10^{6} / \mathrm{ml}$. FITC-Annexin $\mathrm{V}(5 \mu \mathrm{l})$ and propidium iodide $(5 \mu \mathrm{l})$ were added to $100 \mu \mathrm{l}$ of the cell suspension and cells were incubated at room temperature for $15 \mathrm{~min}$ in the dark. After incubation, $400 \mu \mathrm{l}$ of $1 \times$ binding buffer was added to the cell suspension and cells were analyzed by two-color cytometry using a FACScan ${ }^{\mathrm{TM}}$ (Becton Dickinson, Franklin Lake, NJ).

\section{Caspase assays}

The activity of caspase 3 in the cells treated with lovastatin was examined by using the Caspase-GloTM 3/7 (Promega, Madison, WI). The assay is based on caspase cleavage of a proluminescent substrate linked with the tetrapeptide DEVD, resulting in the generation of a "glow-type" luminescent signal, produced by luciferase. In brief, cells were treated as described above and cytosolic extracts were prepared by suspension of cell pellets in NP-40 lysis buffer $(10 \mathrm{mM}$ Tris$\mathrm{HCl}, \mathrm{pH}$ 8.0, $5 \mathrm{mM} \mathrm{Mg}(\mathrm{OAc})_{2}, 90 \mathrm{mM} \mathrm{KCl}, 0.2 \mathrm{mM}$ PMSF, 100 units $/ \mathrm{ml}$ aprotinin, $10 \mu \mathrm{g} / \mathrm{ml}$ leupeptin and $2 \% \mathrm{NP}-40$ ). After centrifugation at $10,000 \mathrm{~g}$ for $5 \mathrm{~min}$, cell extracts containing $40 \mu \mathrm{g}$ proteins were transferred into a 96-well plate to mix with $50 \mu \mathrm{l}$ of the Caspase-Glo3/7 reagent added. After incubation for $1 \mathrm{~h}$ at $37^{\circ} \mathrm{C}$, caspase activity was determined by a fluorescent plate reader (Microtiter Plate Luminometer, Dynex Technologies, Chantilly, VA).

\section{Western blot analysis}

After treatments, cells were washed twice with ice-cold phosphate-buffered saline (PBS) and collected with a scraper. Cytoplasmic extracts were prepared by suspension of cell pellets in NP-40 lysis buffer as described above. After centrifugation at $10,000 \times g$ in a microcentrifuge at $4^{\circ} \mathrm{C}$ for $10 \mathrm{~min}$, cell extracts (100 $\mu \mathrm{g}$ per sample) were fractionated on SDS-10\% polyacrylamide gels and transferred to PVDF membranes (Millipore, Billerica, MA). The membranes were blocked with 5\% nonfat milk in PBS containing $0.02 \%$ sodium azide and $0.2 \%$ (v/v) Tween 20 , and incubated with different primary antibodies for $1 \mathrm{~h}$ at room temperature. The membranes were then washed with PBS containing $0.2 \%(\mathrm{v} / \mathrm{v})$ Tween 20 and incubated with specific secondary antibodies conjugated with horseradish peroxidase (Cell Signaling, Billerica, MA) for $1 \mathrm{~h}$ at room temperature. After washing, these proteins were detected by a chemiluminescence method according to the manufacturer's specification (Pierce, Rockford, IL).

Anchorage-independent cell growth

LMP agar $(0.6 \%)$ in $3 \mathrm{ml}$ of $1 \times$ MEM plus $10 \%$ FBS was poured in each well of a six-well plate. After the gel was solidified, ovarian cancer cells $\left(6 \times 10^{3}\right)$ mixing with $3 \mathrm{ml}$ of $0.35 \%$ LMP agar in $1 \times$ MEM plus $10 \%$ FBS were laid on the top of previous gel in each well. The plate was incubated in a humidified atmosphere of $5 \% \mathrm{CO}_{2}$ at $37^{\circ} \mathrm{C}$ for 1-2 weeks. The cell colonies were counted and the pictures were taken under Olympus model CKX31 at 100x magnification at day 7 and 14 .

\section{Results}

Statins induce apoptosis in ovarian cancer cells

Statins are well known for their cholesterol-lowering effect. Recent studies have revealed that statins inhibit certain cancer cell proliferation, invasion and migration in vitro and in vivo [9-16]. To determine the direct effect of statins on ovarian cancer cells, we treated Hey 1B cells, a human ovarian carcinoma cell line, with lovastatin, a member of the statin family, at various doses for $48 \mathrm{~h}$ and the lovastatin-induced Hey 1B cell death could be observed by a phase contrast microscope (Fig.1a). To rule out the possibility that this result was cell line specific, Ovcar-3 cells, another ovarian cancer cell line, were treated with lovastatin (Fig.1b) and similar results were obtained. Lovastatin is a product of fungal fermentation in the statin family. To determine, if other statin members have the same effect on ovarian cancer cells, we treated Hey 1B and Ovcar-3 cells with atorvastatin, a synthetic compound in this family. As shown in Fig. 1a, b, atorvastatin exerted a similar effect on these ovarian cancer cells. The data indicated that statins at $10 \mu \mathrm{M}$ were sufficient to induce ovarian cancer cell death in vitro.

To quantitatively analyze statin-induced ovarian cancer cell death, the viability of Hey 1B cells in the presence or absence of $10 \mu \mathrm{M}$ lovastatin was analyzed using MTT assay according to the manufacturer's instructions. MTT [3-(4,5-dimethylthiazol-2-yl)2,5-diphenyl tetrazolium bromide] is a compound that can be taken up by viable cells and reduced by a mitochondrial dehydrogenase forming a formazan product in living cells. The absorbance of the formazan product at $490 \mathrm{~nm}$ is in linear proportion to cell numbers. As shown in Fig. 2, the cell viability dramatically 
Fig. 1 Photomicrographs of Hey 1B and Ovcar-3 cells after treatment with lovastatin and atorvastatin. Photographs of the unstained cells were taken under Olympus model CKX31 at $\times 100$ magnification after $48 \mathrm{~h}$ of treatment of Hey 1B (a) and Ovcar- 3 cells (b) with different doses of lovastatin and atorvastatin
A

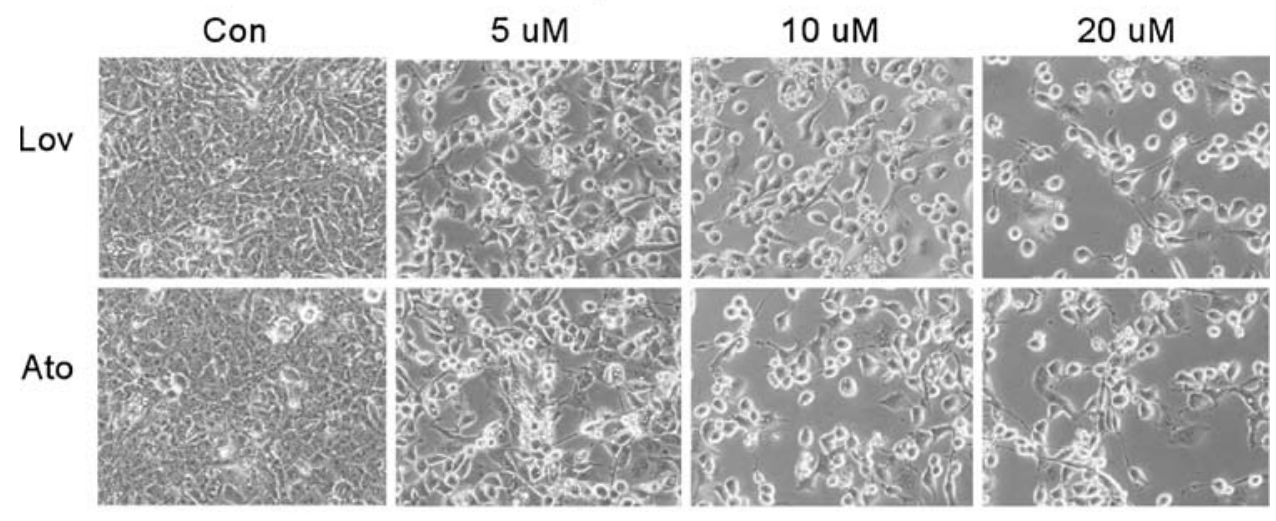

Ovcar-3

B

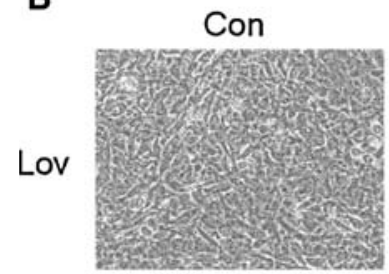

$5 \mathrm{uM}$ $10 \mathrm{uM}$

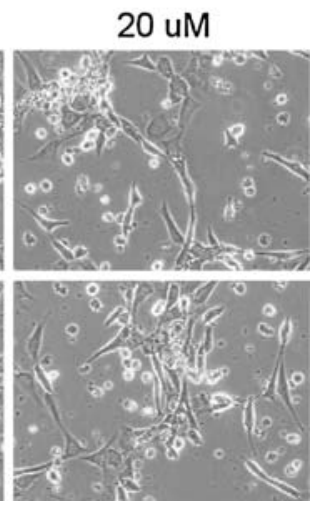

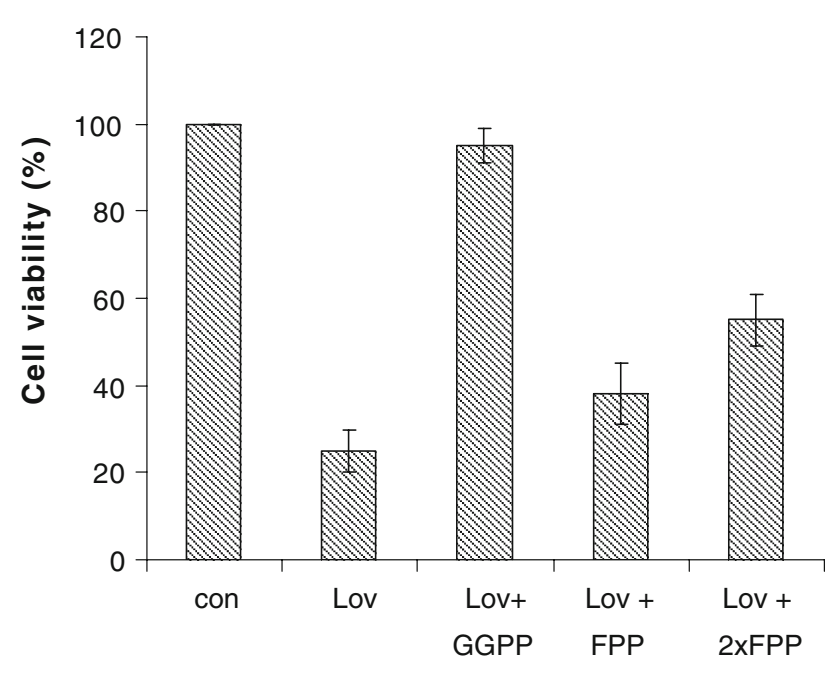

Fig. 2 Effect of lovastatin on Hey 1B cell viability Hey 1B cells were treated with $10 \mu \mathrm{M}$ lovastatin for $48 \mathrm{~h}$ in the presence or absence of $2.5 \mu \mathrm{M}$ GGPP or $2.5 \mu \mathrm{M}$ and $5 \mu \mathrm{M}$ FPP. The percentage of viable cells was measured by using MTT assay (Promega). Experiments were performed three times in triplicate. Data are presented as mean $\pm \mathrm{SD}$

decreased after Hey 1B cells were treated with lovastatin. Atorvastatin treatment produced a similar result (data not shown).
Inhibition of HMG-CoA reductase by statins results in the depletion of several intermediates products in the mevalonate pathway. These intermediates include farnesypyrophosphate (FPP) and geranylgeranylpyrophosphate (GGPP)-isoprenoids that serve as the substrates for the prenylation of Ras and Rho family of small GTPases, respectively. To determine whether supplementation of GGPP or FPP is able to prevent cells from death, Hey 1B cells were co-incubated with $10 \mu \mathrm{M}$ lovastatin and $2.5 \mu \mathrm{M}$ GGPP or FPP. Treatment of Hey 1B cells with GGPP almost completely prevented cell death induced by lovastatin, but FPP only had a partial effect. These results indicate that blockage of the geranylgeranylation may be more important than prevention of farnesylation for lovastatininduced Hey 1B cell death (Fig. 2).

To determine whether the decreased viability of Hey 1B cells is due to lovastatin or atorvastatin-induced apoptosis, Annexin V assay was performed. The translocation of membrane phospholipid phosphatidylserine (PS) from the inner to the outer leaflet of the plasma membrane is an early event of cell apoptosis. Annexin V is a $35-36 \mathrm{kD} \mathrm{Ca}^{2+}$ dependent, phospholipid-binding protein that has a high affinity for PS. Therefore, FITC-conjugated Annexin V is commonly used to identify apoptotic cells at an early stage. 
Hey $1 \mathrm{~B}$ cells were treated with $10 \mu \mathrm{M}$ of lovastatin for $48 \mathrm{~h}$ and subjected to Annexin V assay (Fig. 3). Lovastatin treatment of Hey 1B cells increased the percentage of apoptotic cells in the late stage (Annexin V and PI positive) from 13 to $48 \%$. While GGPP reduced the percentage to $18.1 \%$, FPP only slightly decreased the percentage of apoptotic cells at that stage to $37.8 \%$. Interestingly, the Annexcin V labeled cell population induced by lovastatin was not significantly changed in response to GGPP. This suggests that while the final stages of apoptosis induced by lovastatin are inhibited by GGPP (Figs. 2, 3), this inhibition occurs at a step subsequent to the externalization of phosphatidylserine. To determine whether lovastatin induces apoptosis immortalized non-cancerous cells, we treated MC3T3-E1, a mouse preosteoblast cell line and WI-38, a human lung fibroblast cell line, with lovastatin. Although lovastatin was able to induce apoptosis in these cells, a higher concentration $(30-50 \mu \mathrm{M})$ and a prolonged incubation time (72$96 \mathrm{~h}$ ) were required to achieve the similar level of apoptosis (data not shown). These results are consistent with the previous reports that lovastatin at a higher concentration is needed to induce apoptosis in myeloma plasma cells, smooth muscle cells and endothelial cells [36-38], suggest- ing that ovarian cancer cells may be particularly vulnerable to statin-induced apoptosis.

Statin treatment activates caspase 3

To characterize further the statin-induced apoptosis in ovarian cancer cells, we determined the activity of caspase 3 in Hey 1B cells after treatment with lovastatin. The activity of caspase 3 in the cells treated with lovastatin was examined by using a Caspase-GloTM 3/7 assay kit (Promega). Lovastatin induced the activity of caspase 3 in Hey 1B cells by 3.5-fold. Consistent with our previous results, supplementation of GGPP was able to block caspase 3 activation induced by lovastatin, more effectively than FPP (Fig. 4).

\section{Statin treatment enhances the expression of GTPases}

Small GTPases act as molecular switches to regulate diverse biochemical functions in all eukaryotic cells through mediating gene expression. Therefore, we investigated the effect of statins on the expression of certain proteins including the members of the small GTPase family. Since we had already determined that inhibition of geranyl-
Fig. 3 Determination of apoptotic cells by Annexin $\mathrm{V}$ assay Hey $1 \mathrm{~B}$ cells were treated with or without $10 \mu \mathrm{M}$ lovastatin for $48 \mathrm{~h}$ in the presence or absence of $2.5 \mu \mathrm{M}$ GGPP and FPP. Apoptotic cells were analyzed by Annexin V assay (BD Pharmingen). Atorvastatin treatment produced a similar result (data not shown)
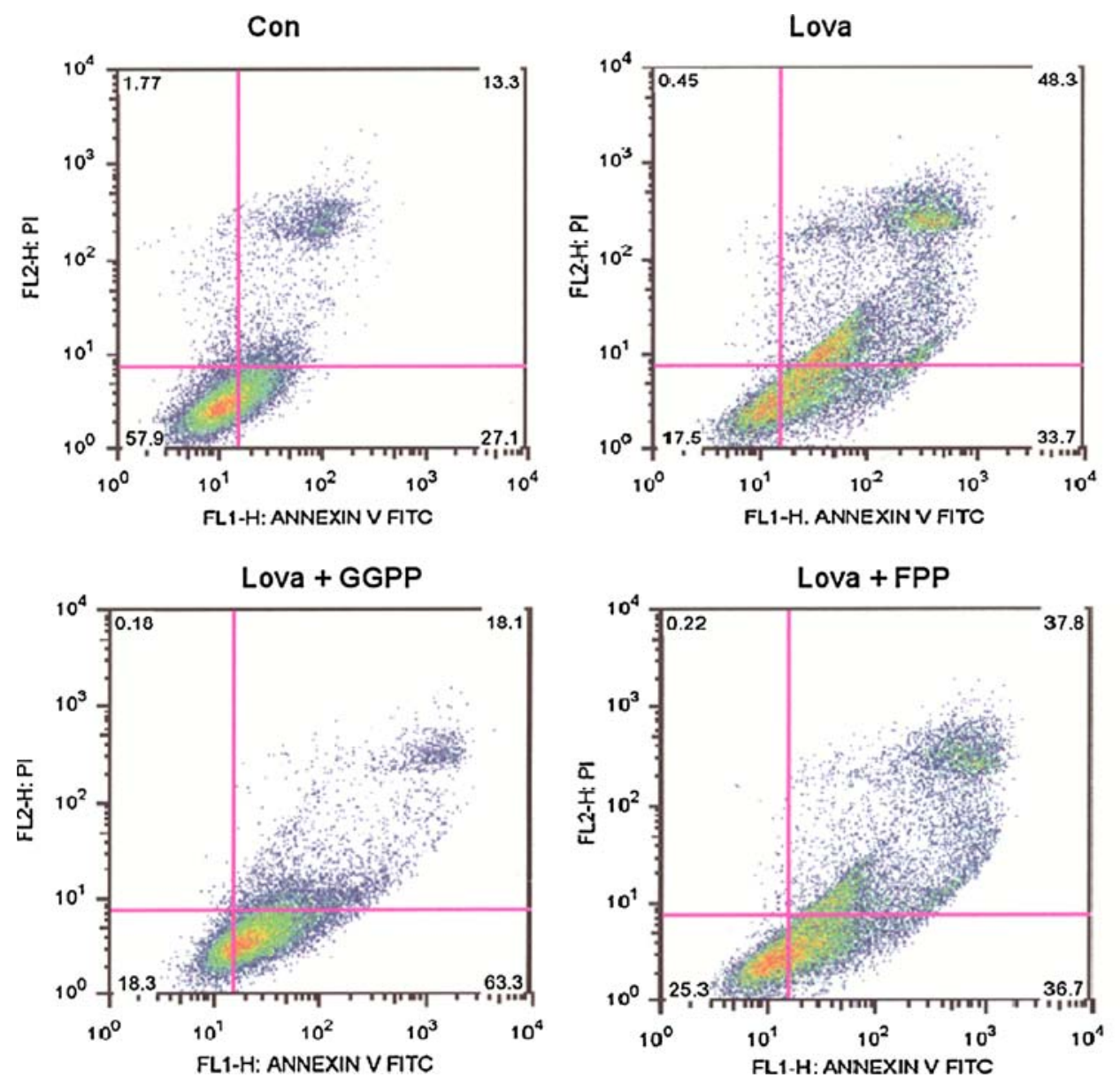


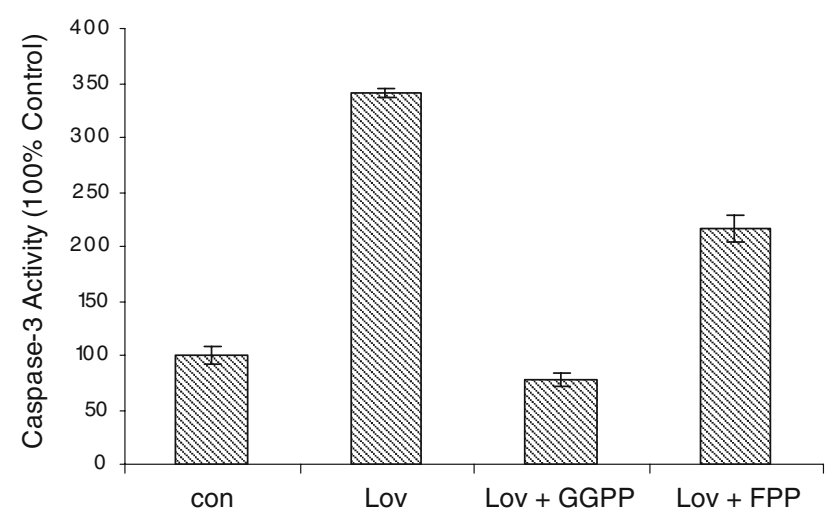

Fig. 4 Induction of caspase 3 activity by lovastatin Hey 1B cells were treated with $10 \mu \mathrm{M}$ lovastatin in the presence or absence of $2.5 \mu \mathrm{M}$ GGPP and FPP. The activity of caspase 3 was assayed using the Caspase-GloTM 3/7 kit (Promega). Data represent two independent experiments in triplicate (mean $\pm \mathrm{SD}$ )

geranylation rather than farnesylation plays a role in statininduced apoptosis in ovarian cancer cells, we focused on the Rho family. Intriguingly, we found that lovastatin significantly induced the expression of Rac1 and $\mathrm{Cdc} 42$, but not RhoA (Fig. 5a, b), in a dose and time-dependent manner. Signaling by Rac1 or Cdc42 is known to activate the JNK pathway resulting in phosphorylation of the transcriptional factor c-Jun. Consistent with this, we also determined an increase of p-c-Jun (Fig. 5a, b). The supplementation of GGPP prevented apoptosis and suppressed the caspase 3 activity in Hey 1B cells induced by statins. This may be due to reduced expression of Rac1 and Cdc42 (Fig. 5c).

Statin treatment augments the level of Bim in ovarian cancer cells

There are varieties of gene products involved in the process of cell apoptosis. A well-known group of these gene products is the Bcl-2 family. The Bcl-2 family includes both anti-apoptotic and pro-apoptotic members. Signaling by the JNK pathway has been linked to altered expression of several Bcl-2 family members in other systems [39]. To determine if the Bcl-2 family plays a role in statin-induced ovarian cell apoptosis, we examined the expression of Bcl2, an anti-apoptotic member, in Hey 1B cells treated with lovastatin. As shown in Fig. 6a, there was no significant difference in the expression level of the protein in cells treated with lovastatin. We also examined the effect of lovastatin on the expression of Bax and Bim, pro-apoptotic members of this family. Interestingly, lovastatin significantly induced the expression of Bim, but not Bax in Hey $1 \mathrm{~B}$ cells in a dose (Fig. 6b) and time (data not shown) dependent manner, suggesting that Bim may mediate lovastatin-induced ovarian cancer cell apoptosis. Pretreatment of Hey 1 B cells with SP600125, an inhibitor of JNK,

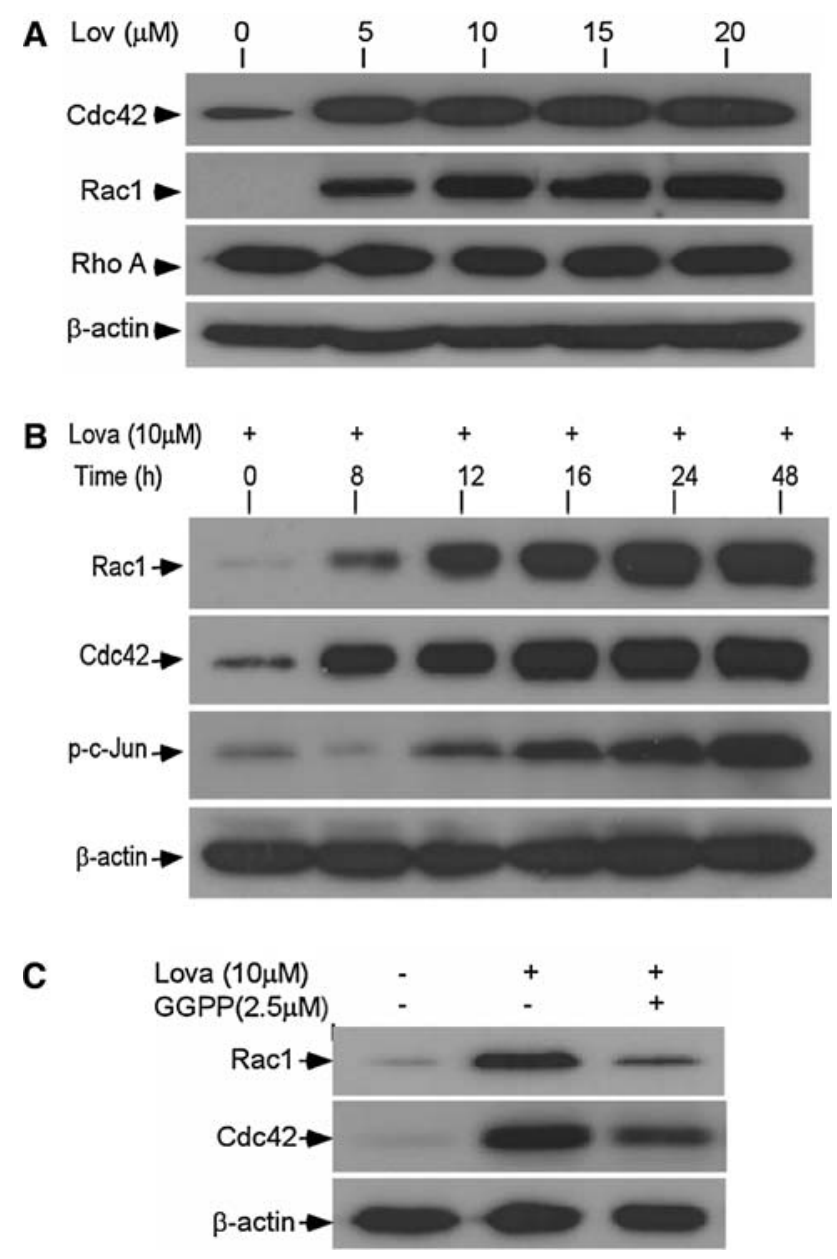

Fig. 5 Lovastatin-induced the expression of Rac1 and Cdc42 Hey 1B cells were treated with different doses of lovastatin for $20 \mathrm{~h} \mathrm{(a);} \mathrm{treated}$ with $10 \mu \mathrm{M}$ lovastatin at different times (b); treated with $10 \mu \mathrm{M}$ lovastatin in the presence or absence of $2.5 \mu \mathrm{M}$ GGPP for $20 \mathrm{~h}$ (c). Proteins in the extracts were separated by $10 \%$ SDS-polyarylamide gel electrophoresis and analyzed by Western blot using antibodies to Rac1, Cdc42, Rho A, p-c-Jun and $\beta$-actin (Santa Cruz)

markedly decreased lovastatin-induced expression of Bim, confirming that JNK activation plays a critical role in statin-induced apoptosis in ovarian cancer cells (Fig. 6c).

Statins inhibit tumor formation in soft agar

Anchorage-independent growth in soft agar is often predictive of tumorigenicity in vivo. Therefore, we performed a soft-agar, colony-formation assay to determine the effect of statins on tumorigenicity of ovarian cancer cells. In this assay, Hey $1 \mathrm{~B}$ cells were incubated in soft agar in the presence or absence of lovastatin or atorvastatin. Interestingly, we found that statins significantly inhibited colony-formation of ovarian cancer cells in soft agar. Colony-forming frequencies in soft agar with $10 \mu \mathrm{M}$ of lovastatin or atorvastatin were roughly 10 -fold lower than that in the control (Fig. 7a). The average colony size was dramatically smaller 


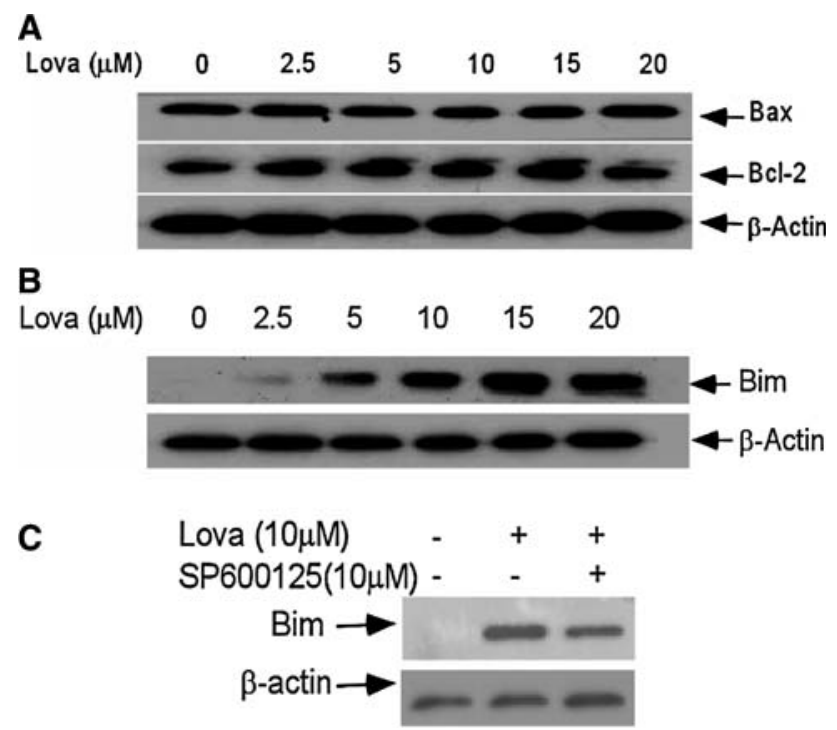

Fig. 6 Effect of lovastatin on the expression of Bcl-2 family members Hey $1 \mathrm{~B}$ cells were treated with $10 \mu \mathrm{M}$ lovastatin for various doses and the expression of the Bcl-2 family members was determined by Western blot analysis using antibodies to Bcl-2 (BD Biosciences), and Bax (Santa Cruz) (a); treated with different doses of lovastatin for $20 \mathrm{~h} \mathrm{(b)}$; pretreated with or without $10 \mu \mathrm{M}$ SP600125 for $2 \mathrm{~h}$ and then treated with $10 \mu \mathrm{M}$ lovastatin for $20 \mathrm{~h}$ (c), and the level of Bim was determined by Western blot analysis using a monoclonal antibody to human Bim (BD Biosciences)

in soft agar containing lovastatin or atorvastatin (data not shown) after incubation for 14 days, suggesting the therapeutic potential of statins in suppression of ovarian tumor growth (Fig. 7b).

\section{Discussion}

Ovarian cancer is often diagnosed at an advanced stage. Thus, although ovarian cancer is the fourth most common cancer in women, it is the leading cause of death among all gynecological malignancies in industrialized countries. The current therapeutic strategy for advance ovarian cancer is a combination of surgery and antimicrotubular chemotherapy. However, a majority of these patients relapses and develops resistance to these chemotherapeutic agents.

The link between the etiology of ovarian cancer and lipid metabolism has been known for decades [40, 41], yet this knowledge has not been exploited in the search for better treatment strategies. In addition to their role in lowering cholesterol, the statin family of drugs has shown a broad range of functions including suppression of cancer cell growth in vitro and in vivo [9-16] in many cell types. Surprisingly, the effect of statins on ovarian cancer is limited to one study documenting lovastatin-induced growth inhibition [35]. In this study, we report that two different statins induce apoptosis in ovarian cancer cells and inhibit growth
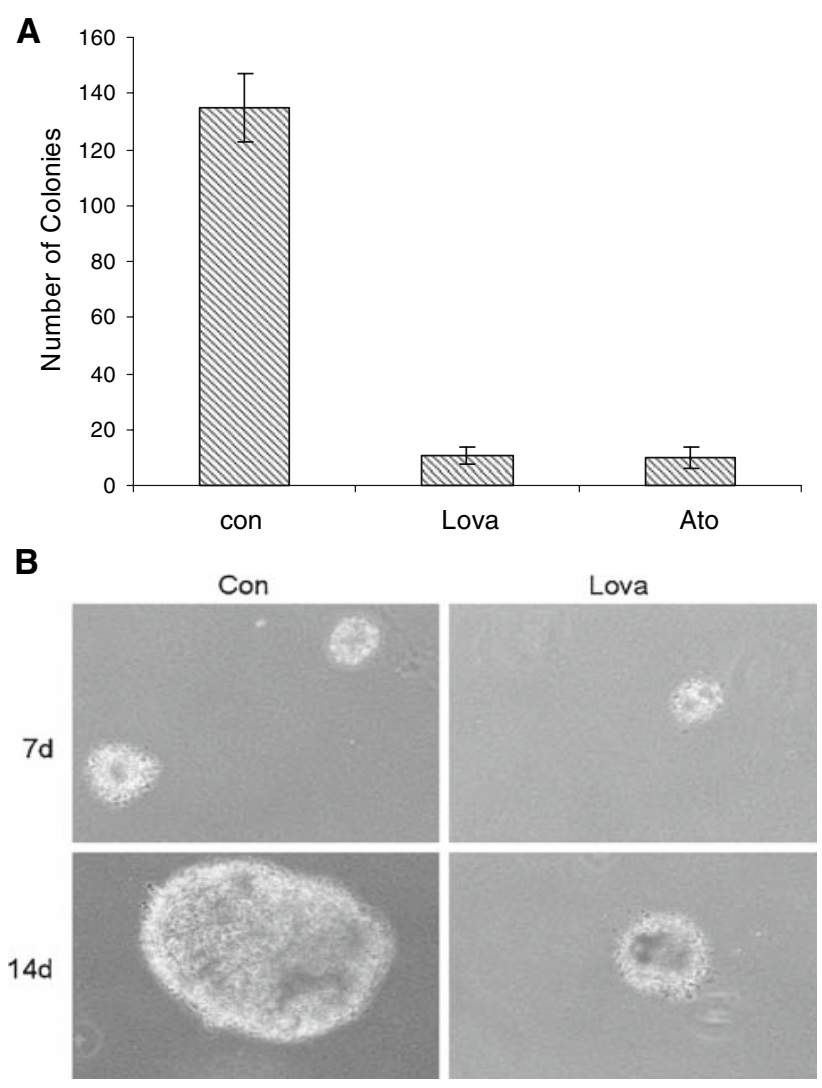

Fig. 7 Effect of statins on anchorage-independent cell growth Hey 1B cells were grown in soft agar in the presence or absence of $10 \mu \mathrm{M}$ lovastatin; visible colonies were counted after crystal violet staining. The mean value $\pm \mathrm{SD}$ of three independent experiments is shown (a). The photos were taken under Olympus model CKX31 at $\times 100$ magnification at day 7 and 14 (b)

of ovarian tumors in soft agar. Our results suggest that statins alone, or possibly in combination with other conventional drugs, may represent a novel therapy for advanced ovarian cancer.

Statins are known to inhibit HMG-CoA reductase and thus can inhibit the prenylation of several G-proteins by reducing geranylgeranylpyrophosphate (GGPP) and farnesylpyrophosphate (FPP). Based on this, the expectation would be that statins would inhibit the signaling of prenylated G-proteins. Recently, however, lovastatin was shown to induce the expression of Rho A, B and C in human erythroleukemia cells and to increase the active GTP-bound form of Rho by 3.7 fold [22]. Further, lovastatin did not affect the prenylation of Ras in erythroleukemia cells, suggesting that inhibition of geranyl-geranylation was more pronounced than inhibition of farnesylation. Neither Rho downstream signaling events nor the status of Rac and cdc 42 were assessed in these cells. Consistent with the finding that statins can increase the expression of geranyl-geranylated G-proteins, we have shown that lovastatin treatment increased the expression of both Rac and Cdc 42 in ovarian 
cancer cells, which could be abolished by inclusion of GGPP but not FPP. However, we did not observe an increase of Rho expression in both Hey $1 \mathrm{~B}$ and Ovar-3 cells after statin treatment. This distinction is most likely a consequence of cell types. Possible mechanisms whereby the inhibition of prenylation could result in increased expression of prenylated G-proteins would include the possibility that either the unprenylated G-protein affects the signaling pathway controlling its own expression, or the lack of prenylation impacts this pathway through some other molecules.

Consistent with the fact that JNK is a downstream target of Rac and cdc 42 signaling [31, 32], and that phosphorylation of the transcription factor c-Jun is downstream of JNK activation, we observed an increase in the level of active, phosphorylated c-jun in the ovarian cancer cells under statin treatment. Further investigation revealed that the expression of Bim, a proapoptotic protein, is significantly induced in the cells by statins. These findings are consistent with the observation that Bim induction in neurons deprived of NGF is regulated by c-Jun [42]. SP600125 is a competitive inhibitor of ATP binding to JNK and some other kinases [43]. Pretreatment of Hey 1B cells with SP600125 significantly reduced lovastatin-induced expression of Bim, confirming the role of JNK in induction of Bim in these cells. Our results demonstrating statin-induced apoptosis and inhibition of anchorage independent growth of ovarian cancer cells suggest the validity of investigating the use of statins as a treatment for ovarian cancer. Further, our investigation of the molecular mechanism involved in statin signaling in ovarian cancer cells provides novel potential targets for therapeutic manipulation.

\section{Conflict of interest statement None.}

\section{References}

1. Sharma S, Odunsi K (2005) Targeted therapy for epithelial ovarian cancer. Expert Opin Ther Targets 9(3):501-513

2. American Cancer Society, http://www.cancer.org

3. Ozols RF (2005) Treatment goals in ovarian cancer. Int J Gynecol Cancer 15(Suppl 1):3-11

4. Du Bois A, Pfisterer J (2005) Future options for first-line therapy of advanced ovarian cancer. Int J Gynecol Cancer 15(Suppl 1):42-50

5. Bookman MA (2005) Gemcitabine monotherapy in recurrent ovarian cancer: from the bench to the clinic. Int J Gynecol Cancer 15(Suppl 1):12-17

6. Caslake MJ, Packard CJ (2004) Phenotypes, genotypes and response to statin therapy. Curr Opin Lipidol 15(4):387-392

7. Stein EA (2003) The power of statins: aggressive lipid lowering. Clin Cardiol 26(4 Suppl 3):III25-31

8. Schmitz G, Drobnik W (2003) Pharmacogenomics and pharmacogenetics of cholesterol-lowering therapy. Clin Chem Lab Med 41(4):581-589

9. Chan KK, Oza AM, Siu LL (2003) The statins as anticancer agents. Clin Cancer Res 9(1):10-19
10. Cafforio P, Dammacco F, Gernone A, Silvestris F (2005) Statins activate the mitochondrial pathway of apoptosis in human lymphoblasts and myeloma cells. Carcinogenesis 26(5):883-891

11. Muck AO, Seeger H, Wallwiener D (2004) Inhibitory effect of statins on the proliferation of human breast cancer cells. Int J Clin Pharmacol Ther 42(12):695-700

12. Koyuturk M, Ersoz M, Altiok N (2004) Simvastatin induces proliferation inhibition and apoptosis in C6 glioma cells via c-jun Nterminal kinase. Neurosci Lett 370(2-3):212-217

13. Otsuki T, Sakaguchi H, Hatayama T, Fujii T, Tsujioka T, Sugihara T, Takata A, Hyodoh F, Eto M (2004) Effects of an HMG-CoA reductase inhibitor, simvastatin, on human myeloma cells. Oncol Rep 11(5):1053-1058

14. Collisson EA, Kleer C, Wu M, De A, Gambhir SS, Merajver SD, Kolodney MS (2003) Atorvastatin prevents RhoC isoprenylation, invasion, and metastasis in human melanoma cells. Mol Cancer Ther 2(10):941-948

15. Gliemroth J, Feyerabend T, Gerlach C, Arnold H, Terzis AJ (2003) Proliferation, migration, and invasion of human glioma cells exposed to fractionated radiotherapy in vitro. Neurosurg Rev 26(3):198-205

16. Holstein SA, Knapp HR, Clamon GH, Murry DJ, Hohl RJ (2005) Pharmacodynamic effects of high dose lovastatin in subjects with advanced malignancies. Cancer Chemother Pharmacol 30:1-10

17. Issat T, Nowis D, Jakobisiak M, Golab J (2004) Lovastatin potentiates antitumor effects of saquinavir against human lymphoma cells. Oncol Rep 12(6):1371-1375

18. Kozar K, Kaminski R, Legat M, Kopec M, Nowis D, Skierski JS, Koronkiewicz M, Jakobisiak M, Golab J (2004) Cerivastatin demonstrates enhanced antitumor activity against human breast cancer cell lines when used in combination with doxorubicin or cisplatin. Int J Oncol 24(5):1149-1157

19. Agarwal B, Bhendwal S, Halmos B, Moss SF, Ramey WG, Holt PR (1999) Lovastatin augments apoptosis induced by chemotherapeutic agents in colon cancer cells. Clin Cancer Res 5(8):22232229

20. Feleszko W, Jakóbisiak M (2000) Lovastatin potentiates antitumor activity and attenuates cardiotoxicity of doxorubicin in three tumor models in mice. Clin Cancer Res 6(5):2044-2052

21. Xiao H, Zhang Q, Lin Y, Reddy BS, Yang CS (2008) Combination of atorvastatin and celecoxib synergistically induces cell cycle arrest and apoptosis in colon cancer cells. Int J Cancer 122(9):21152124

22. Turner SJ, Zhuang S, Zhang T, Boss GR, Pilz RB (2008) Effects of lovastatin on Rho isoform expression, activity, and association with guanine nucleotide dissociation inhibitors. Biochem Pharmacol 75(2):405-413

23. Bokoch GM, Diebold BA (2002) Current molecular models for NADPH oxidase regulation by Rac GTPase. Blood 100(8):26922696

24. Rul W, Zugasti O, Roux P, Peyssonnaux C, Eychene A, Franke TF, Lenormand P, Fort P, Hibner U (2002) Activation of ERK, controlled by Rac1 and Cdc42 via Akt, is required for anoikis. Ann NY Acad Sci 973:145-148

25. Frost JA, Steen H, Shapiro P, Lewis T, Ahn N, Shaw PE, Cobb MH (1991) Cross-cascade activation of ERKs and ternary complex factors by Rho family proteins. EMBO J 16(21):6426-6438

26. Clerk A, Pham FH, Fuller SJ, Sahai E, Aktories K, Marais R, Marshall C, Sugden PH (2001) Regulation of mitogen-activated protein kinases in cardiac myocytes through the small $\mathrm{G}$ protein Rac1. Mol Cell Biol 21(4):1173-1184

27. Keely PJ, Westwick JK, Whitehead IP, Der CJ, Parise LV (1997) Cdc42 and Rac1 induce integrin-mediated cell motility and invasiveness through PI(3)K. Nature 390(6660):632-636

28. Aznar S, Lacal JC (2001) Rho signals to cell growth and apoptosis. Cancer Lett 165(1):1-10 
29. Chuang TH, Hahn KM, Lee JD, Danley DE, Bokoch GM (1997) The small GTPase Cdc42 initiates an apoptotic signaling pathway in Jurkat T lymphocytes. Mol Biol Cell 8(9):1687-1698

30. Subauste MC, Von Herrath M, Benard V, Chamberlain CE, Chuang TH, Chu K, Bokoch GM, Hahn KM (2000) Rho family proteins modulate rapid apoptosis induced by cytotoxic $\mathrm{T}$ lymphocytes and Fas. J Biol Chem 275(13):9725-9733

31. Minden A, Lin A, Claret FX, Abo A, Karin M (1995) Selective activation of the JNK signaling cascade and c-Jun transcriptional activity by the small GTPases Rac and Cdc42Hs. Cell 81(7):1147-1157

32. Coso OA, Chiariello M, Yu JC, Teramoto H, Crespo P, Xu N, Miki T, Gutkind JS (1995) The small GTP-binding proteins Rac1 and Cdc42 regulate the activity of the JNK/SAPK signaling pathway. Cell 81(7):1137-1146

33. Teramoto H, Coso OA, Miyata H, Igishi T, Miki T, Gutkind JS (1996) Signaling from the small GTP-binding proteins Rac1 and $\mathrm{Cdc} 42$ to the c-Jun $\mathrm{N}$-terminal kinase/stress-activated protein kinase pathway. A role for mixed lineage kinase 3/protein-tyrosine kinase 1 , a novel member of the mixed lineage kinase family. J Biol Chem 271(44):27225-27228

34. Chuang TH, Hahn KM, Lee JD, Danley DE, Bokoch GM (1997) The small GTPase Cdc42 initiates an apoptotic signaling pathway in Jurkat T lymphocytes. Mol Biol Cell 8(9):1687-1698

35. Melichar B, Ferrandina G, Verschraegen CF, Loercher A, Abbruzzese JL, Freedman RS (1998) Growth inhibitory effects of aromatic fatty acids on ovarian tumor cell lines. Clin Cancer Res 4(12):3069-3076

36. van de Donk NW, Kamphuis MM, van Kessel B, Lokhorst HM, Bloem AC (2003) Inhibition of protein geranylgeranylation induces apoptosis in myeloma plasma cells by reducing Mcl-1 protein levels. Blood 102(9):3354-3362

37. Erl W, Hristov M, Neureuter M, Yan ZQ, Hansson GK, Weber PC (2003) HMG-CoA reductase inhibitors induce apoptosis in neointima-derived vascular smooth muscle cells. Atherosclerosis 169:251-258

38. Kaneta S, Satoh K, Kano S, Kanda M, Ichihara K (2003) All hydrophobic HMG-CoA reductase inhibitors induce apoptotic death in rat pulmonary vein endothelial cells. Atherosclerosis 170:237-243

39. Zhu BK, Wang P, Zhang XD, Jiang CC, Chen LH, Avery-Kiejda KA, Watts R, Hersey P (2008) Activation of Jun N-terminal kinase is a mediator of vincristine-induced apoptosis of melanoma cells. Anticancer Drugs 19(2):189-200

40. Avall-Lundqvist EH, Peterson CO (1996) Serum cholesterol and apolipoprotein B levels may reflect disease activity in ovarian cancer patients. Acta Oncol 35(8):1007-1010

41. Risch HA, Jain M, Marrett LD, Howe GR (1994) Dietary fat intake and risk of epithelial ovarian cancer. $\mathrm{J}$ Natl Cancer Inst 86(18):1409-1415

42. Biswas SC, Shi Y, Sproul A, Greene LA (2007) Pro-apoptotic Bim induction in response to nerve growth factor deprivation requires simultaneous activation of three different death signaling pathways. J Biol Chem 282(40):29368-29374

43. Bennett BL, Sasaki DT, Murray BW, O'Leary EC, Sakata ST, Xu W, Leisten JC, Motiwala A, Pierce S, Satoh Y, Bhagwat SS, Manning AM, Anderson DW (2001) SP600125, an anthrapyrazolone inhibitor of Jun N-terminal kinase. Proc Natl Acad Sci USA 98(24):13681-13686 